\title{
CHURCH, STATE, AND MORAL VALUES: THE LIMITS OF AMERICAN PLURALISM
}

\author{
James HitchCock* \\ I \\ INTRODUCTION
}

Through most of its history America has been perceived as a predominantly religious nation, with relatively high rates of church attendance, numerous public expressions of piety, and a general assumption that civic and private virtue depend on religious belief. The 1950's marked perhaps the peak of that diffuse religiosity, when the idea of religious belief and observance was maximally honored, often apart from commitment to any of its specific forms. Billboards urged citizens to "Attend church this week," as though church-attendance were a self-evidently good thing and as though it made little difference which church one attended, or why.

Although this kind of social piety might be thought mere conformism, and as such lacking in substance, it was intended to symbolize certain realities. For one thing it was intended to affirm that America was a nation of church-going and God-fearing people, an affirmation of national commitment that transcended particular differences or particular examples of infidelity. For another, it was an affirmation of the belief that morality itself, the basis without which any civilized existence would be impossible, depended upon religion. Thus it was essential to affirm that commitment as a way of affirming one's belief in the social contract itself.

Although moral values are notoriously elusive of investigation, it also appears to be the case that until the 1960's Americans held to a fairly general consensus on such values, a consensus which was celebrated in political and civic rhetoric, extolled from a wide variety of pulpits, honored in the mass media, and to a great extent perpetuated through formal education, both public and private. This consensus included as its key factors the self-evident rightness of patriotism, selfdiscipline, hard work, self-reliance, family stability, personal honesty, and sensual self-restraint. However dishonored in practice, these virtues received consistent public affirmation, and were usually thought of as based on religious belief.

From the beginning there has always been a fundamental ambivalence in America about the degree to which the society is and should be what is now called "pluralistic," that is, how wide a diversity of beliefs and practices are and may be tolerated. That such ambivalence has been present from the beginning is evident to anyone with even minimal knowledge of early American history. School children

Copyright (C) 1981 by Duke University.

* Professor of History, St. Louis University. 
learn that the early settlers of New England came seeking religious freedom. As they get a little older they also learn that those same settlers denied religious freedom to others.

The temptation is to dismiss the Puritans as hypocrites. But in their own minds they were totally consistent-there was a moral obligation to tolerate religious truth, which not even kings could abridge; there was no obligation, and indeed no right, to tolerate religious error. Put in more modern and more secular terms, the earliest American settlers affirmed the desirability of greater freedom than existed in the Old World, yet believed with equal conviction that society had to rest on a common moral consensus. At various times in history this consensus has been thought to exclude Quakers, Catholics, Jews, and other religious groups. Sooner or later, however, excluded groups have been understood in such a way as to permit them to be part of the consensus. Although most Americans would probably say that there is full religious freedom in the country, certain practices dictated by religious beliefs are in fact outlawed-polygamy, snake-handling, and the withholding of medical treatment from sick children are the most obvious examples.

Whether rightly or wrongly, most Americans prior to the 1960's probably perceived a fundamental moral consensus underlying a variety of religious denominations unequalled in world history in terms of number and diversity of beliefs. Equally important, this consensus was assumed to embrace even the majority of those who had no real religious belief. Relatively few public figures would admit to such a condition, and nominal church affiliation - often with liberal groups such as the Unitarians- was a way of concealing it. Direct attacks on the broadly conceived "Judeo-Christian ethic" were rare, except perhaps in relatively protected and insulated environments such as college campuses.

The 1960's and 1970's saw a definite decline in church membership and attendance, sometimes a very sharp decline. ${ }^{1}$ More important than the numerical fluctuation, which has tended towards a rather irregular historical pattern, has been the fact that a secular way of life is now more respectable in America that at perhaps any time in the twentieth century - understanding secularism first in the narrower sense of rejection of institutional religion and then in the broader sense of making no claim of being guided by the teachings of the historical religions. Not only do public figures now find it unnecessary to claim religious affiliation; in certain segments of society such claims are becoming increasingly rare. A frankly secularist stance enjoys a prestige equal to that of religious belief.

It would, however, be a mistake to understand what has happened in America since about 1960 as merely a division between the churched and the unchurched. The division, within each denomination, between what are often called, borrowing the vocabulary of politics, "liberal" and "conservative" elements, has been equally important. Although such divisions, in one form or another, have been a part of American religious life almost from the beginning, they took on unusual sharpness

1. For a discussion of church membership and religious practice, see D. Kelly, Why THE Conservative Churches are Growing 8 (1973) and D. Hoge \& D. Roozen, Understanding Church Growth AND DECline, 1950-78 (1979). 
and deepening passion after 1960. To cite merely a few examples-the changes in the Roman Catholic Church either mandated by the Second Vatican Council of 1962-65 or implemented in its name, the decision of the Episcopal Church to ordain women to the priesthood and to authorize a new edition of the Book of Common Prayer, disagreements within major Protestant bodies over the exact nature of the authority of Scripture and the extent of its inerrancy, and possibly widening divisions within Judaism over the authority of traditional religious laws and practices.

In most of these cases it could be argued with cogency than the more "liberal" groups came to be perceived as having perhaps more in common with secularists outside their framework of formal religion than with the "conservatives" within their own churches. Liberals have tended to emphasize a political agenda, for example, which is critical of the American economic system and of America's role in world affairs, an agenda shared in large measure with the secular left. Religious liberals have tended to support, quite strongly, feminism, the movement for homosexual rights, and much of what goes under the name of the "sexual revolution." One major divergence between themselves and the religious conservatives is precisely their attitudes toward secular movements of social change, liberals being inclined to recognize these as actual manifestations of the divine will, conservatives seeing them as frontal assault on the Judeo-Christian ethic. Thus in 1980 certain religious leaders could join with proclaimed secularists like the television producer Norman Lear in issuing a public warning against the organization called the Moral Majority. ${ }^{2}$ The warning was issued in response to the widespread impression that, as a new decade began, there was a "swing to the right" in which religious conservatives were once against asserting what they regarded as traditional American values which had been transgressed.

The liberal critique of American society is in large measure the claim that, while based on the ideal of total openness or "pluralism," in practice it has always been more closed and monolithic than it should be. To what degree America was intended originally to be totally "open" is itself an open question. Through much of the nineteenth century there were legal restrictions on personal freedom which today would be regarded as intolerable, slavery being only the most obvious example. Among the Founding Fathers the commitment to civil liberties was not as complete as in retrospect civil-libertarians find it useful to believe. ${ }^{3}$ However, history aside, it is the essence of the liberal position that the story of America is the story of the gradual extension and unfolding of that pluralism, the full encompassment of more and more diverse groups and hitherto proscribed beliefs and behavior. Liberty is regarded as capital which cannot simply be allowed to lie secure but must always be expanded, often with considerable elements of risk. Although many would have difficulty expressing the moral sources of that imperative, liberals are generally convinced that there exists a moral obligation on America to broaden continually the limits of its tolerance. So far as racial, ethnic, and religious

2. A national letter went out over Lear's signature (copy in possession of the author).

3. L. Levy, Jefferson and Civil Liberties: The Darker Side (1963). 
groups are concerned this point has, at least in principle, been won completely. It has now been extended to other categories of people, such as women as a group, who are assumed to have specific rights which must be guaranteed apart from the guarantee of rights to all citizens; to cultural minorities like homosexuals; and to all those who profess "deviant" ideas or ways of life. Both the reality of and the potentiality for social conflict in these areas is, if anything, greater than it was with respect to struggles for racial equality.

In general the liberal response to this conflict is to insist that it is based on a misapprehension, which in turn is based on fear and insecurity. The purpose of an extended pluralism, the liberal argument runs, is simply to extend the rights of citizenship to all Americans, to remove all vestiges of inequality and injustice. America means equality, so the argument runs, and only when the rights of everyone are fully protected are the rights of anyone really secure. Resistance to this is then deemed to originate from one of two causes - simple bigotry, the wish to keep others in an inferior status; or unfounded fear that the extension of some people's rights will result in the constriction of one's own.

Probably not since the days of slavery has American politics confronted issues with moral roots running so deep as those now on the political agenda. Questions like abortion, the relationship between men and women, and personal sexual behavior are not easily dealt with in a political context, and instinctively politicians in times past have tried to evade questions likely to touch such deep nerves. But the commitment to a steadily expanding pluralism makes confrontation with such questions unavoidable. With most traditional struggles over equality won at least in principle, the new frontiers necessarily are defined in places hitherto inaccessible to political intrusion.

This new phase of the struggle for equality will of necessity test the limits of American pluralism in ways they have never been tested before. This will occur (and indeed is already occurring) in part because it raises issues that go to the heart of deeply held and fundamental moral beliefs which cannot be easily compromised and where the mutual respect, which makes democratic dialogue possible, is often lacking. (Abortion is an obvious example. Some people regard it as one of a woman's most basic rights, others as the deliberate killing of a helpless human being. In such circumstances there is not much room for "statesmanlike" solutions.)

Another test of the limits of pluralism is the question as to what unifying principle remains at the heart of a society as that society becomes more and more diverse, especially in terms of accepted moral values. A society can tolerate a certain number of positions which are antithetical to each other. Is there a limit beyond which these antitheses become socially destructive? The moral revolution since 1960 has tended to call into question, systematically, virtually one by one, every settled belief from the past. It has now become a political question whether a social order can survive based on no moral consensus. (To cite only the most obvious question, what motivates people to obey the law, and to what extent, in the absence of such a consensus?)

Thirdly, it is necessary to ask the question whether society can be indefinitely 
pluralistic, indefinitely tolerant of all points of view, while still maintaining genuine equality among them all. At some point does the legitimization of some positions necessarily require the constriction of others? It will be the purpose of this paper to argue that, where fundamental values are involved, this is precisely the case, and the question, which touches many areas of social life, will be considered primarily from the point of view of those issues which touch directly or indirectly on religious belief and practice.

\section{II}

\section{The Wall of Separation}

The separationist clause of the First Amendment is admittedly very general in nature, using only ten words, and as such is subject to a number of possible interpretations. For some time after the ratification of the Constitution some of the states continued to maintain relationships between church and state which later constitutional doctrine would regard as unacceptable. ${ }^{4}$

Thomas Jefferson's phrase, "wall of separation of church and state" was first used, in passing, by the Supreme Court in $1878,{ }^{5}$ then resurrected after many decades of neglect in $1947 .{ }^{6}$ Since the latter date it has come to be thought of as the governing metaphor in the area of church-state relations, and it has come to be the purpose of much litigation in that area of constitutional law to ferret out systematically all signs of public support of religion.

Oddly, however, in an age when few traditional assumptions have been left unchallenged, there has been relatively little discussion of why an absolute wall of church-state separation is necessary. It remains one of the few basic principles still treated as self-evidently true, even though it is far from self-evident that the First Amendment mandates such a doctrine.

Mark DeWolfe Howe argued a double tradition of church-state separation in American history: one essentially secular, deriving from Jefferson and James Madison, and seeking to protect the public weal from the intrusion of religion; the other older, derived from colonial figures like Roger Williams, wanting to insure maximum freedom for the churches without government interference. Howe argued that the first strain has generally governed separationist thinking. ${ }^{7}$

Judging from the rhetoric both of some of the Founding Fathers and of later court decisions, commitment to the separationist dogma has its origins in the Enlightenment of the eighteenth century, an age highly conscious of the seemingly "irrational" passions which religion could stir up, still suffering from the aftermath of religious wars which had been common in the previous two centuries, persuaded

4. See, e.g., A. Stokes, Church and State in the United States (1950) (3 vols.); C. Antieau, A. Downey, \& E. Roberts, Freedom from Federal Establishment: Formation and Early History of the First amendment Religion Clauses (1964); and S. Cobb, The Rise of Religious Liberty in the UNITED STATES (1902).

5. Reynolds v. United States, 98 U.S. 145, 164 (1878).

6. McCullom v. Board of Educ., 333 U.S. 203, 231 (1948).

7. M. Howe, The Garden and the Wilderness 6-7 (1962). 
that organized religion was almost the natural enemy of freedom. ${ }^{8}$ The principal motive for absolute separation was to protect society from destructive religious quarrels, which were deemed uniquely intense and dangerous.

Justice Hugo Black articulated the same viewpoint in 1952:

It was precisely because Eighteenth Century Americans were a religious people divided into many fighting sects that we were given a constitutional mandate to keep Church and State completely separate. Colonial history had already shown that, here as elsewhere, sectarians entrusted with governmental power to further their causes would sometimes torture, maim, and kill those they branded "heretics," "atheists," or "agnostics."

Justice Felix Frankfurter had similarly warned that "the public school must keep scrupulously free from entanglement in the strife of sects," 10 and Justice Robert Jackson had written, "If we are to eliminate everything that is objectionable to any of these warring sects or inconsistent with any of their doctrines, we will leave public education in shreds." In cases involving religion, the courts have tended to employ "sect" as a favorite synonym for organized religion, implying factionalized conflict.

If, however, the peculiar horror in which the courts seem to hold religious conflict can be seen as a holdover from eighteenth century history and attitudes, it has assumed the character of an unquestioned assumption of eternal validity. Thus Chief Justice Warren Burger could write in 1969:

Ordinarily political debate and division, however vigorous or even partisan, are normal and healthy manifestations of our democratic system of government, but political division along religious lines was one of the principal evils against which the First Amendment was intended to protect. ${ }^{12}$

A statement of this kind automatically invites the question "why." In an age when the acceptable limits of political controversy have broadened considerably, when freedom of speech is deemed necessarily to include the expression of many divisive and potentially inflammatory ideas, it is not clear why disagreement along religious lines should be held in peculiar horror. Arguably, in the America of the 1980's political divisions along the lines of race, economic status, even perhaps gender, are actually and potentially more divisive than religious divisions. Furthermore, it hardly seems consistent with the governing spirit of liberal democracy to inhibit certain expressions of belief because these might be potentially divisive. Supposedly such "divisiveness" is not only the price paid for a real democracy but almost in a sense the very essence of that democracy, and it ought not to be the business of the courts to protect society from such disruptions.

At present it remains unproven that religious division constitutes a uniquely dangerous threat to political stability and, if it indeed is, that it is of such magni-

8. See, e.g., R. Healy, Jefferson on Religion and Public Education 162, 211, 216-19, 225 (1962)

9. Zorach v. Clauson, 343 U.S. 306, 318-19 (1952).

10. McCullom v. Board of Educ., 333 U.S. 203, $216-17$ (1948).

11. Id., at 235

12. Lemon v. Kurtzman, 403 U.S. 602, 622 (1971). 
tude as to require systematic vigilance by the courts against it. Both assumptions, however, seem to lie behind the strict separationist position which the courts have accepted in large measure.

The "wall of separation" is often presented as a high constitutional principle which, perhaps reluctantly, the courts must apply even when regrettable inconveniences occur. Thus it is argued, for example, that if children attending a rural parochial school on a cold winter's morning are given a ride on a public-school bus, the entire American tradition of church-state separation is endangered.

It is worth noting that the pragmatic liberal mind does not ordinarily countenance what seem like harsh conclusions in support of abstract principles. That mind in fact prides itself on its ability to adjust principle (including law) to social reality. For this reason alone it is unlikely that abstract principle of itself governs the strict separationist position. In practice it appears that much of that position has been carved out in response to pressures from sources which regard either organized religion in general or specific religious groups as undesirable social institutions. To an extent greater than is generally realized, the separationist doctrine rests on anti-religious foundations.

That Thomas Jefferson and some other of the Founding Fathers felt this hostility is well known. ${ }^{13}$ However, it was built into law over the years in sometimes surprising ways-not until 1978 did the Supreme Court invalidate a Tennessee law, for example, prohibiting clergymen from holding public office. ${ }^{14}$

The personal views of the judges are scarcely irrelevant to the question. As indicated by his statement above, Justice Black, for one, seems to have regarded religious believers as uniquely likely to torture, maim, and kill in the name of their beliefs and thus to be needful of restraint from so doing. His son revealed that the Justice regarded people who attended church as "hypocrites" and had a particular dislike of the Catholic Church. (As a young lawyer in Alabama, Black successfully represented a Methodist minister accused of killing a Catholic priest. The defendant's guilt was not seriously in doubt, but Black exploited the anti-Catholic sentiments of the jurors. ${ }^{15}$ )

In several of the cases involving the question of public aid to religious schools, the principle has been enunciated that the character of those schools is itself objectionable. In Lemon $v$. Kurtzman, ${ }^{16}$ for example, Justice William O. Douglas stated that, while it was the purpose of the public schools to educate, it was the purpose of Catholic schools to indoctrinate. ${ }^{17}$ His source for this sweeping statement was a book by a fundamentalist Protestant author claiming to make an exposé of the Catholic Church. The book claimed, among other things, that

13. See, e.g., Healy, supra note 8 .

14. McDaniel v. Paty, 435 U.S. 618 (1978).

15. H. Black Jr., My Father, A Remembrance (1975); V. Hamilton, Hugo Black: The Alabama YEARS (1972).

16. 403 U.S. 602 (1971)

17. Id., at 635 . 
Catholic priests and religious teachers are not allowed to think, that parochial schools represent a dangerous "foreign" influence in the United States, and that they produce a disproportionate number of gangsters and juvenile delinquents. The author concluded by recommending that Catholics not be allowed to teach in public schools or hold high public office. ${ }^{18}$ In his extra-judicial writings Douglas revealed that he was influenced by the anti-Catholic polemicist Paul Blanshard. ${ }^{19}$

The suspicion that teachers in religious schools cannot be relied on to teach even secular subjects in a proper manner was expressed by Chief Justice Burger and Justice Black in Lemon, ${ }^{20}$ bringing from Justice White the observation that nothing in the judicial record actually showed that secular subjects were being taught improperly. ${ }^{21}$ Justice Jackson wrote in Everson v. Board of Education ${ }^{22}$ "[o]ur public school, if not a product of Protestantism, at least is more consistent with it than with the Catholic culture and scheme of values."23

Prior to World War II church-state cases before the Supreme Court were relatively rare. There was a spate of conscientious-objection cases at the start of World War II. Since then, beginning in 1947, there has been a steady flow of church-state cases, immeasurably broadening the scope of constitutional law in this area. In general the courts have tended towards a strict separationist position. ${ }^{24}$

The leading historian of the phenomenon has noted that for the most part these cases were carefully chosen and prepared and were designed to establish sweeping constitutional principles. Often they did not grow out of genuine social conflicts so much as from the desire of the plaintiffs to make a philosophical point. While skilled constitutional lawyers usually represented the plaintiffs, defendants' lawyers, especially where public agencies like school boards were concerned, rarely had much experience in constitutional matters and not infrequently had no particular commitment to the positions they were defending. In addition, strict separationists were generally on the offensive, acting as plaintiffs in 53 of 67 major church-state cases between 1951 and $1971 .^{25}$

Three organizations played important roles in the long-term separationist strategy: the American Civil Liberties Union (A.C.L.U.), the American Jewish Congress (A.J.C.), and Protestants and Other Americans United for Separation of Church and State (P.O.A.U.), now Americans for Separation of Church and State. ${ }^{26}$ In all three cases, besides constitutional principle, participants were at least sometimes motivated by antipathy to the Catholic Church and by the belief that Catholic schools are a pernicious influence in society. P.O.A.U. is the most obvious casedating back many years it had warned Americans, frequently in tones of alarm,

18. L. Boettner, Roman Catholicism 360-63, 364, 368, 370, 379-80 (1962).

19. W. Douglas, The Bible and the Schools 50 (1966).

20. Lemon v. Kurtzman, 403 U.S. 602, 618, 635-36 (1971).

21. Id., at 667 .

22. 330 U.S. 1 (1947)

23. Id., at 23

24. F. Sorauf, The Wall of Separation: The Constitutional Politics of Church and State 9, 19, 21 (1976).

25. Id, at $30-33,89,106-11,165,349-50$

26. Id., at 31-33. 
that the Catholic Church constituted a threat to democracy and that Catholics could not be good Americans. ${ }^{27}$ (Its rhetoric has moderated in recent years.) In one case brought by the A.C.L.U., the plaintiff was a woman who believed that religious education deforms minds in the same way that Chinese foot-binding deformed women's feet. ${ }^{28}$ Leo Pfeffer, counsel for the A.J.C. and probably the most effective separationist lawyer over the past thirty years, admits to a personal dislike of Catholic schools, which he regards as undemocratic. ${ }^{29}$

It is arguable that the strict separationist position, which was only adopted by the courts after World War II, represents the triumph of those who regard organized religion as an actual or potential danger to the Republic. As such it is not an even-handed application of some principle of neutrality so much as it is the enshrining in law of a particular philosophy. ${ }^{30}$

\section{III}

\section{Separation versus Liberty}

As it applies to religion, the First Amendment contains two clauses, the second, ensuring free exercise of religion, being only slightly shorter than the first. If the extent of the separationist clause is in some doubt, the extent of the free-exercise clause is not. From the beginning of the United States it has been clear that there were to be no restrictions of religious liberty except in very extreme cases, such as the Mormon practice of polygamy in the nineteenth century.

Liberal opinion has generally held that the two clauses are perfectly complementary to each other, that the separation clause is in fact a necessary prerequisite of the free-exercise clause, since church-state entanglement would itself pose a serious threat to religious liberty. However, in practice it has often been necessary for the courts to choose between them, and a judicial policy of remaining vigilant against church-state entanglement in practice often means the willingness to impose, or to allow others to impose, burdens on the free exercise of religion.

The dilemma would be less acute under a regnant judicial philosophy which regards the interpretation of the Constitution as a narrow and technical matter, in which it is the business of the judges to expound the law as written, whatever practical consequences might flow from that. However, for many years the reigning judicial philosophy has concerned itself quite consciously with the real or potential social affects of court decisions. The frequency with which the courts have shown a willingness to permit disabilities in the exercise of religious freedom, for the sake of maintaining strict separation, indicates what is often a deliberate choice on the judges' part.

27. For an example of P.O.A.U. rhetoric, see C. Lowell, The Great Church-State Fraud (1973). For a sample and refutation of such rhetoric over the span of a decade, see L. CREedon \& W. FALCON, United for Separation: P.A.O.U. Assaults on Catholicism (1959).

28. Sorauf, supra note 20 , at 135 .

29. Pfeffer, The "Catholic" Catholic Problem, Commonweal, Aug. 1, 1975, at 302-03.

30. See the article by Francis Canavan in this issue, The Pluralist Game, 44:2 LAw \& Contemp. ProB., Spring 1981, at 23. 
The most obvious example is public aid to religious schools. It would be difficult to show that concrete harm comes to the body politic as a result of such aid, or that such aid necessarily would deprive religious schools of their independence. Countries with political structures comparable to the United StatesCanada, Australia, and the Netherlands, for example-have maintained such aid programs for many years without serious ill effect.

The strict separationist argument rests rather on abstract principle-that such aid is in itself bad, because it violates a self-evident principle. But the evident correctness of the principle is precisely what is in question. When it does not rest on abstract principle the argument against such aid is usually based on the fact that some people object to the use of their taxes for purposes of which they disapprove or in which they do not believe. But the Constitution provides no guarantee that one's taxes will only be used in ways compatible with one's beliefs. Given the immense size and complexity of the federal budget, virtually any taxpayer could discover numerous uses of tax money of which he or she morally disapproves. It appears to be only in the area of religion that the courts have recognized a quasi-right of taxpayers to object to specific uses of their tax money.

Court decisions with regard to school aid have been somewhat inconsistent. However, in general they have tended to forbid all direct or indirect forms of such aid at the primary and secondary levels, while allowing it for the most part at the level of colleges and universities. ${ }^{31}$ During the period when these cases were under litigation, and particularly since about 1965, many private religious schools, especially those under Catholic auspices, closed because of financial pressures. If it is assumed that church-operated schools are an important exercise of religious freedom, if it is assumed that by operating schools the churches are performing a vital social service, and if it is recognized that parents who send their children to religious schools are also taxpayers, it would seem that the state has a compelling interest in seeing to it that these schools are as good as they can be and are not starved for funds. The courts have in general tended to hold that people cannot effectively exercise their rights if they lack the financial means to do so (thus, for example, the provision of free legal services for indigent defendants). In the area of religion, however, it often appears that the courts, from a separationist standpoint, take a certain satisfaction in permitting as many financial burdens as possible to develop. The general tendency in modern society is for the state to find ways of aiding institutions which, even though private, are deemed worthy of survival, a pattern which prevails from hospitals to zoos and includes symphony orchestras and groups which provide contraceptive and abortion services. Religious schools almost alone remain outside this pattern, often because they are regarded as social institutions which should not survive or whose survival should be made difficult.

Along with school aid, the question of religious observances in the public

31. The principal Supreme Court cases are: Everson v. Board of Educ., 330 U.S. 1 (1947); Board of Educ. v. Allen, 392 U.S. 236 (1967); Lemon v. Kurtzman, 403 U.S. 602 (1971); Committee for Public Educ. \& Religious Liberty v. Nyquist, 413 U.S. 756 (1973); Meek v. Pittenger, 421 U.S. 349 , reh. denied, 422 U.S. 1049 (1975); Wolman v. Walter, 433 U.S. 229 (1977); Roemer v. Maryland Pub. Works Bd., 426 U.S. 736 (1976). 
schools has provided the bulk of the church-state cases of the past thirty-five years. While there have been some seeming inconsistencies, in general the courts have systematically banned all overt religious instruction, along with prayers, readings from Scriptures, and religious symbolism. Reluctantly, they have allowed, under certain circumstances, children in public schools to be released from regular classes in order to attend religious instruction off school premises. ${ }^{32}$

The religious elements banned from the schools have usually been studiously non-denominational in character. Thus the courts have ruled not only against the favoring of any particular religion but against the favoring of religion in general. The schools are to be scrupulously neutral where matters of religion are concerned.

How neutral they can be in practice is something which will be discussed later. There are, however, certain other aspects of this position which are questionable. Beginning in 1948, it has been a consistent claim by plaintiffs in separationist suits that their rights are violated if religious observances, however generalized, are imposed on them. One such early case, for example, held that even though children receiving religious instruction in a public school left the regular classroom, those who remained behind were subjected to embarrassment and possible harassment. ${ }^{33}$ However, on other occasions the Supreme Court has specifically said that, in the words of Justice Jackson, "If we are to eliminate everything which is objectionable to any of these warring sects or inconsistent with any of their doctrines, we will leave public education in shreds." ${ }^{34}$ It sometimes appears in court decisions that there exists a constitutional right on the part of non-believers to be protected from unpalatable impositions of religious beliefs, but no corresponding right on the part of believers to be protected from ideas which they find offensive.

The strict separationist position also seems incompatible with prevailing trends in modern education. It was more defensible when schools were regarded as having a primarily technical role-they were to teach young people skills like reading, writing, and arithmetic, which could be seen as divorced from larger questions of meaning and value. Now, however, schools tend to stress "total" education and are seen as institutions which shape young people in myriad ways, of which the strictly academic is only a part. Furthermore, it has been a general tendency in modern education to hold that children should not be insulated from controversial and even disturbing aspects of reality.

Given these views of education, any system which resolutely excludes religion is already an anomaly. If the schools are regarded as helping to shape the child's total world, then the exclusion of religion cannot help but shape a religionless world. At the most formative period of their lives, children are in effect taught that religion is unimportant or even perhaps false. They are habituated in modes of thinking and feeling in which religion plays no part. Although the school may

32. The principal Supreme Court cases are: McCollum v. Board of Educ., 333 U.S. 203 (1948): Zorach v. Clauson, 343 U.S. 306 (1952); Engel v. Vitale, 370 U.S. 421 (1962); Abington School Dist. v. Schempp, 374 U.S. 203 (1963).

33. McCollum v. Board of Educ., 333 U.S. 203 (1948).

34. Id., at 235 . 
deliberately seek to introduce the child to "controversial" subjects, religion cannot be one of these. The very exclusion itself has major symbolic importance.

Several remedies are proposed. One is that religion be taught as an academic subject, rather like geography. But in practice this does not appear to be very common and in any case does not have much bearing on an education which seeks to prepare children for "life."

More common is the assertion that religious education is properly the business of the family and the church. But this begs the question. Parents send their children to school precisely because they feel incompetent to educate them at home. And although strong family practice is probably an essential prerequisite for instilling religious belief in a child, in many homes this practice may be relatively inarticulate and unsophisticated. Churches have access to children for only a very few hours a week, not in any way comparable to the time they spend in school. There are many functions currently performed by the schools that might be performed adequately by other agencies. When any of these is in fact relegated to other agencies, the school is conveying to the child the idea that such is not really important.

Cases in which strict separationism has been applied in such a way as seemingly to limit religious freedom have become fairly common: Currently under appeal to the Supreme Court is a case in which a federal circuit court permitted a student organization to use campus facilities for a Bible-study group. ${ }^{35} \mathrm{~A}$ district court ${ }^{36}$ had originally upheld the university's decision to forbid such use. At another state university, student religious groups are restricted in the number of meetings they may hold on campus and are required to pay rent for the facilities, conditions not imposed on other student groups. A state court upheld such restrictions and granted university authorities the right to impose prior restraint on such meetings, on the grounds that there was a "clear and present danger" of violation of the establishment clause. ${ }^{37}$

Such cases have arisen at a time when the overwhelming tendency of courts, and of universities and colleges themselves, has been to expand the limits of student freedom and to hold that all manner of "controversial" opinions have a right to be heard. They have also arisen in an atmosphere in which the tendency of courts has been to protect constitutional freedoms not only in narrowly procedural ways but also by seeking to identify substantive violations of freedom which may seem technically legal. The trend in church-state cases seems to go contrary to both these tendencies.

\section{IV}

\section{Public Neutrality}

The theory of separationism holds that the state is and must be neutral in matters of religion. But, as suggested previously, such neutrality is difficult to attain

35. Chess v. Widmar, 635 F.2d 1310 (8th Cir. 1980), cert. granted,-U.S.-(1981).

36. Chess v. Widmar, 480 F. Supp. 907 (W.D. Mo. 1979).

37. Dittman v. Western Washington University, No. C79-1189W (W.D. Wash., Feb. 28, 1980). 
in practice. There can be little doubt that present separationist safeguards do insure government neutrality among religious groups-public policy does not seem to favor Christians over Jews, for example, or Catholics over Protestants. However, it is a more substantial question whether public policy can and does maintain effective neutrality between religion and unbelief, between professed theism and other kinds of faith which can be thought of as competing with it.

To maintain that such neutrality is possible seems to require postulating that public policy is somehow arrived at in a "value-free" manner. Yet it would be difficult to show any policies which are in fact completely neutral. At the lowest level, certain policy decisions may be purely functional in that they merely involve choices as to how to achieve particular goals. Yet the goals themselves, at a higher level of policy-making, cannot be "value-free." Certain values may be assumed to be commonly shared throughout the body politic. However, it is one of the arguments of this paper that such common assumptions are becoming fewer in number. Furthermore, even within the framework of common assumptions, important value judgments must often be made which involve sharp conflict.

A classic example, already alluded to, was the Supreme Court's 1878 decision outlawing polygamy as practiced by Mormons in the Western United States. On one level the decision was clearly a limitation on religious freedom. The Court reached its decision by positing the existence of an over-riding value-the welfare of society required the support of a stable, legal family in the traditional sense, which polygamy would tend to undermine. (The court also made a distinction, which proved not to be very useful, between freedom of religious beliefs on the one hand and religious actions on the other, which might be restricted by law. ${ }^{38}$ ) The court assumed a commonly held value-the legally established nuclear familywhich was one of the givens of American society. Today there are many people who would reject that given, and it seems likely that a similar case today might be decided quite differently.

The common liberal argument for pluralism at this point asserts that the law merely expands the limits of permissible belief and behavior. In the process no one suffers; people may find certain ideas distasteful or invalid, but they are not required to accept them, merely to tolerate them. With regard to polygamy, for example, some people might be permitted in law to practice it, but others could still enter into traditional marriages.

Such a philosophy is totally out of step with the overwhelming tendency of modern government, however, which seems almost inevitably set on a course of expansion of powers and expansion of the ways in which it intervenes in the lives of its citizens. The minimal government envisioned by classical conservative theory might conceivably claim the kind of neutrality which pluralism postulates. The modern, activist, liberal, welfare state cannot be neutral and does not aim to be.

Public education, as already discussed, is a prime case in point. No responsible educator would deny that education involves the making of countless value judgments-in establishing curricula, choosing teachers, mandating textbooks, set-

38. Reynolds v. United States, 98 U.S. 145 (1878). 
ting goals, etc. Many of these judgments involve moral choices which may be controversial. The very absence of religion is, as already argued, a judgment of this kind. Contrary to the beliefs of many people, the courts and the schools have decided that education is best carried out with no religious component at all.

One of the relatively few instances in which opponents of strict separationism have taken the offensive in litigating constitutional questions has been recent cases in which Protestants of the type generally called fundamentalist have sued school districts to force the inclusion of biblical accounts of creation alongside the theory of evolution in their curricula or, alternatively, to present evolution as merely a theory rather than a fact. Plaintiffs contend that the teaching of evolution alone violates their religious beliefs and also violates the required neutrality of the state. ${ }^{39}$

A more widespread and perhaps more sensitive area of conflict is over sex education in the public schools. Such programs have become all but universal and perhaps arouse more public controversy than any other aspect of education. The standard argument in favor of such programs is that they are indeed neutral-they merely impart information to students which is deemed appropriate for students to have. But the very existence of such programs involves a value judgment, since some parents oppose them on moral grounds and assert that sex education belongs to the domain of the family. Others would approve such programs, but only if they included explicit moral guidance about sexual behavior. In reality, it appears that many such programs aim at shaping children's values and attitudes with regard to sex. The general assumption behind such programs is that being "sexually active" in a variety of ways is normal and healthy for young people and that the schools should help them to do so safely and without guilt. ${ }^{40}$ Such aims conflict directly with the moral and religious beliefs of many parents, who thus perceive the schools as directly undermining their own attempts to inculcate values in their children. Legal challenges to such programs have generally been unsuccessful. It is not even clear that courts will recognize a general right of exemption from such programs for children whose parents disapprove. ${ }^{41}$ In any case, in some of its earlier decisions, the Supreme Court seemed to say that it is insufficient merely to exempt certain children from programs which violate their consciences, since this may single them out for ridicule and harassment. ${ }^{42}$

If the public schools are the most obvious place where values clash, they are by no means the only cockpit. Abortion is another classic example. The liberal positionthat those who oppose abortion are free not to engage in it, while those who approve it may do so-simply begs the question, since in the minds of antiabortionists they are being asked to countenance the massive taking of human life. A possible compromise over the abortion issue would be to permit abortions to be

39. Epperson v. Arkansas, 393 U.S. 97 (1968); Daniel v. Walters, 515 F.2d 485 (6th Cir. 1975).

40. For a critique of such programs, see Horner, Is the New Sex Education Going Too Far?, New York Times Magazine, Dec. 7, 1980, at 137-48.

41. See, e.g., Cornwell v. State Board of Educ., 428 F.2d 471 (4th Cir.), cert. denied, 400 U.S. 942 (1970).

42. See, e.g., McCollum v. Board of Educ., 333 U.S. 203, 227, 232 (1948). 
performed by private agencies but to keep the state scrupulously neutral. Virtually no one, however, finds this acceptable. Pro-abortionists generally wish to see major governmental support for the practice-it is regarded as an integral part of health care, as well as an important tool in population control, and as such should be promoted by publicly funded agencies both domestically and abroad. The modern welfare state simply cannot remain neutral on such issues.

Recognizing this, suit was brought in federal court to invalidate the so-called Hyde Amendment whereby Congress forbids most expenditures of public funds for abortions. The major grounds for the suit was the claim that the law violated church-state separation because it enacted the principles of particular religions, notably the Roman Catholic Church. Under the so-called "divisiveness" doctrine, the claim was made that any legislation which could be shown to have been influenced primarily by religious believers was invalid because of its tendency to promote religious conflict in society. Plaintiffs went to the length of reading the mail of the congressional sponsor of the legislation, to determine the religious affiliation of those who wrote to him, and of submitting an affidavit about his personal religious practices. The Supreme Court ultimately rejected the argument. $^{43}$

Had it won acceptance, it would have had immensely far-reaching consequences, since a great deal of legislation (for example, the Civil Rights Act of 1964) ${ }^{44}$ could be shown to have been passed as a result of strong religious pressures. At some level the divisiveness doctrine--the argument that certain kinds of state action are forbidden simply because they tend to create religious controversy-is recognized by the Supreme Court, however. It was enunciated by Chief Justice Burger in one of the school-aid cases. ${ }^{45}$ The very fact that the issue is raised tends to demonstrate the impossibility of the state's neutrality in matters of basic values.

Another point of conflict between the professed neutrality of the state and its actual commitment to certain values is the question whether policies to which the state is in principle committed may be enforced with regard to religious institutions which claim exemption either in terms of religious freedom or church-state separation. The Supreme Court, by a narrow margin, has ruled that the National Labor Relations Board does not have jurisdiction over teachers in religious schools. The Catholic hierarchy argued in the case that to permit such a thing would be to permit the government to intervene in disputes which might be of a purely religious nature, e.g., a decision to dismiss a teacher for failing to teach Catholic doctrine. ${ }^{46}$ A Protestant school has successfully argued in a state court that regulations imposed on the school by the state effectively interfered with religious freedom by restricting the school's right to set its curriculum and hire teachers in

43. Harris v. McRae, 448 U.S. 297 (1980) (copy of plaintiff's brief in possession of the author).

44. For the importance of religious influence on legislation, see J. Adams, The Growing Church LobBy in Washington (1970). The Civil Rights Act is considered at 1-3.

45. Lemon v. Kurtzman, 403 U.S. 602,622 (1971).

46. NLRB v. Catholic Bishop of Chicago, 440 U.S. 490 (1979). 
accordance with its religious mission. ${ }^{47}$ Largely unlitigated, at least at the federal level, is the question whether religious institutions, contrary to their professed beliefs, would be prohibited from discriminating against classes of persons specially protected by law, for example, by excluding women from the ranks of the clergy or refusing to hire homosexuals as teachers.

It is worth noting that certain strict separationists do not altogether regard the wall as excluding both sides equally. Leo Pfeffer, for example, notes that church and state historically have sought to dominate each other, with the state usually successful. ${ }^{48} \mathrm{He}$ also argues that some of the Supreme Court's decisions of the past thirty years have made the "liberalization" of the Catholic Church more likely by making parochial schools harder to maintain, thus helping those in the Church who seek a "congregational" polity independent of hierarchical control. Pfeffer believes all religions, partly as a result of court decisions, are fated to become irresistibly secularized. ${ }^{49}$

\section{$\mathrm{V}$ \\ Definition of RELIGION}

Through most of American history, questions of church-state relations have been fairly easy to define because there were few problems as to what constituted a church. However, the First Amendment does not mention "church" but rather "religion." Implicitly, therefore, it seems as though the amendment does not only apply to formally organized groups which designate themselves as churches. America has always been fruitful in producing new religions, and in the past twenty years there has been a vast proliferation of them, the constitutional import of which is not clear.

Insofar as newer religious movements can be readily identified as such there is no problem, since presumably they have the same rights and are subject to the same restraints as older and more established churches. The problem emerges with respect to movements which may not declare themselves to be religions, and may in fact even deny that they are, but which others understand to be. An issue has arisen which respect to the movement called Transcendental Meditation, whose proponents claim that it is merely a technique for recollection and self-exploration, while critics claim it is a religion actually or potentially in conflict with other religions. Thus far Federal courts have upheld the critics. ${ }^{50}$

A potentially much more divisive issue is over the "religion" of Secular Humanism. Many religious believers are convinced that there exists such a philosophy, which is antithetical to theism, dismissing the latter's claims as illusory and hence as

47. Sheridan Road Baptist Church v. Michigan Dept. of Educ., Cir. Ct., Mich., No. 80-26205-AZ (Dec. 8, 1980).

48. L. Pfeffer, Church, State, and Freedom 727 (1953).

49. L. Pfeffer, God, Caesar, and the Constitution: The Court as Referee of Church-State Confrontation 49, 231, 250, 253, 348 (1975).

50. Malnak v. Yogi, 592 F.2d 197 (3d Cir. 1979). 
personally and socially damaging to those who accept them. Secular Humanism also advocates an approach to life in which human beings are encouraged to rely entirely on their own powers and to live and act as though no divine being governs the universe. Finally, certain practical consequences tend to flow from these theoretical beliefs-for example, Secular Humanists tend to reject the traditional, strict Judeo-Christian moral code with regard to sex and to advocate "free" and "open" attitudes towards sexuality which are morally objectionable to many religious believers. ${ }^{51}$

However, it is not the contention of critics that Secular Humanism is merely the doctrine of a particular organization having relatively few members. They rather contend that it is a widely held philosophy of life shared by many people, not all of whom would even be familiar with the name. For purposes of the First Amendment the contention is that Secular Humanism often functions as the governing philosophy of many public schools and other public agencies and that it is not subject to the same restraints in the name of separation that organized churches are. Thus, the argument runs, religious believers suffer violation of their rights by having an alien and unacceptable philosophy imposed on them. Thus far the courts have shown no inclination to accept this argument. ${ }^{52}$

That the courts should take the argument more seriously is suggested by the fact that the Supreme Court, in establishing the criteria for valid conscientious objection from military service, has itself declared Secular Humanism to be a religion, entitled therefore to the same considerations and protections as all other religions. In one such case the Court ruled that:

We believe that ... the test of belief "in a relation to a Supreme Being" is whether a given belief that is sincere and meaningful occupies a place in the life of its possessor parallel to that filled by the orthodox belief in God of one who clearly qualifies for exemption. ${ }^{53}$

If Secular Humanism is indeed a religion for the Court's purposes, and if religion is to be understood as the Court thus understands it, it seems to follow that very difficult and profound questions are raised with respect to the duty of the state to be vigilant against Secular Humanist intrusions into the public order in the same way it is required to be vigilant against theistic intrusions. It is noteworthy that no less a personage than Leo Pfeffer argues that the courts have indeed enshrined Secular Humanism as the official creed. ${ }^{54}$

The issue raises once again the anomaly discussed in relation to the unexamined assumptions of the strict separationists, namely, why it is to be assumed that theistic creeds alone, of all the schools of thought which contend with each other in modern society, are to be singled out for special exclusions.

51. A convenient summary of secular humanist doctrine is found in American Humanist Association, Humanist Manifesto I \& II (1953, 1973).

52. See, e.g., Hobolth v. Greenway, 52 Mich. App. 682, 218 N.W.2d 98 (1974); Medeiros v. Kiyosaki, 52 Haw. 436, 478 P.2d 314 (1970).

53. United States v. Seeger, 380 U.S. 163, 165-66 (1965). See also Torcaso v. Watkins, 367 U.S. 488, 495 (1961).

54. Issues That Divide: The Triumph of Secular Humanism, 1977 J. OF Church \& State 203-05. 


\section{Personal Conscience versus Public Policy}

Instinctively the liberal mind tends to uphold individual rights, especially those based on conscience, when these conflict with law or government policy. A long tradition holds that individual rights must be scrupulously respected, and even dissent from law must be accommodated as much as possible.

It remains uncertain, however, how far the courts will go in permitting dissent on religious grounds from firmly established law or public policy. Historically the Supreme Court has gone fairly far in upholding the right of Jehovah's Witnesses, for example, not to be compelled to salute the American flag ${ }^{55}$ or of Amish parents not to be forced to send their children to public schools. ${ }^{56}$ However, as one constitutional scholar has somewhat cynically suggested, the courts have a record of solicitousness towards religious beliefs perceived as marginal and dissenting while tending towards strictness and vigilance with respect to "mainline" beliefs. ${ }^{57}$

An acute area of conflict has been the growing tendency of some Protestants to establish their own schools. Such establishments have come under attack by various government agencies, including the Internal Revenue Service (charging improper claims of tax exemption) and state departments of education demanding control of accreditation. The results so far have been rather mixed. In each case, however, the supporters of the schools in question claim that conscience, particularly relating to freedom of religion, forbids them to enroll their children in public schools. ${ }^{58}$ More radical yet is the contention of some parents that the moral character of existing schools requires them to educate their children at home, in accord with their own beliefs. Again the judicial results have been mixed. ${ }^{59}$

Parents have also brought suit to overturn compulsory sex-education courses in public schools, on the grounds that such courses violate the religious and moral beliefs of the parents. Such claims have been disallowed. ${ }^{60}$

The practice of "deprogramming" of recruits to various religious sects also raises questions of religious freedom which are far-reaching in their consequences. On the one hand the state seems to have a clear obligation to protect those who are tricked or coerced into joining groups which suppress their freedom, as in the notorious case of the People's Temple of Rev. Jim Jones. However, in the nature of things it is extremely difficult for the state to determine when an individual has indeed been subjected to techniques which negate personal freedom, and the very attempt to do so may have a "chilling" effect on religious liberty. Once the state takes it upon itself to judge when religious conversions are genuine and when the result of forced means, there would be no end to the necessary interference in

55. Board of Educ. v. Barnette, 319 U.S. 624 (1943).

56. Wisconsin v. Yoder, 406 U.S. 205 (1972).

57. W. Berns, The First Amendment and the Future of American Democracy $77-79$ (1976).

58. See, e.g., Kentucky State Bd. v. Rudasill, 589 S.W.2d 877 (Ky. 1979).

59. See, e.g., Michigan v. Noble, No. 5791-0115-A (1979).

60. Note 35 , supra. 
matters of conscience and religious liberty. ${ }^{61}$ It is also worth noting in this connection that some modern sceptics believe that all religious commitment is by definition irrational and therefore might be subject to automatic suspicion and review.

Attempts to "deprogram" members of religious cults are often brought by the members' parents, and the whole area of parental authority is a sensitive one in which the ground appears to be shifting. It is also a subject closely intertwined with personal religious liberty, as indicated in the instances cited above in which parents object on grounds of principle to what is taught in the public schools. The Supreme Court has already ruled that minor children have a right to contraceptive and abortion services without their parents' consent, ${ }^{62}$ a ruling which offends the consciences of many parents not only in its substance but also in the way that it seems to establish the authority of the state above that of the parent in a highly sensitive and important area of life-the nurture of children. Some parents with traditional beliefs fear that the state will indefinitely expand the scope of children's rights so as to minimize parental authority, especially in the crucial area of moral values, and that the state will commit itself to certain policies, e.g., the encouragement of sexual activity among the young, that will directly conflict with parents' own values.

VII

\section{SUMMARY}

As American society, often led by its courts, has greatly widened the limits of permissible belief and behavior over the past twenty years, it has not simply enriched the "pluralism" which has always been a feature of that society. In the nature of things the decision to tolerate certain hitherto disapproved ideas or actions has often required tightening restrictions on ideas or actions previously considered orthodox. An indefinitely elastic pluralism is not possible. Expansions in some areas are likely to cause contractions in others.

In particular the unofficially privileged place which organized religion has traditionally enjoyed in American life has been eroded, often with active judicial effort towards that end. The urge to ensure that non-belief does not suffer in comparison with belief has often led to practical and theoretical restrictions being placed on religion itself. The classical doctrine of strict separationism rests on an assumption that the state can and must be neutral. But in practice this is impossible. Values are necessary for the functioning of any society, and if they are not consciously adopted and publicly acknowledged they will be smuggled in surreptitiously and often unconsciously. Values are always in real or potential conflict, and the state inevitably favors some values over others.

61. Alexander v. Unification Church of America, 634 F.2d 673 (2d Cir. 1980); Peterson v. Sorlien, 299 N.W.2d 123 (Minn. 1980).

62. Planned Parenthood of Missouri v. Danforth, 428 U.S. 52 (1976). Note, however, that the Court has recently limited Danforth. Although it remains unconstitutional to legislate an irrevocable power to parents to forbid their daughter's abortion, a state may require parental notification, when possible, of an abortion to be performed on a dependent unmarried minor. H. L. v. Matheson, 49 U.S.L.W. 4255 (U.S. March 24, 1981) (No. 79-5903) 
